\title{
Sustainable forest management in the Yukon: A new beginning
}

\author{
by Jeff Monty ${ }^{1}$
}

\section{Introduction}

Forest management in the Yukon is entering a new phase of enlightenment ushered in by the United Nations Brundland Commission report, Our Common Future, released in 1987. The report's proposed concept of "sustainable development" shifted forest policy, with ecosystem sustainability becoming a major focus of forest management.

According to the State of Canada's Forests 1996-1997 (Natural Resources Canada 1997), the Yukon's boreal forests cover approximately 60 percent (or $275000 \mathrm{~km}^{2}$ ) of the Yukon's $478000 \mathrm{~km}^{2}$ land base and represents about five per cent of Canada's total forested land. Slightly more than a quarter of the Yukon's forested land is considered "productive" $\left(75000 \mathrm{~km}^{2}\right)$ or biologically capable of producing economical timber harvests within a reasonable time. White spruce (Picea glauca (Moench Voss) makes up two thirds of the merchantable wood volume in these productive forests with average stand volumes ranging from 100 to $250 \mathrm{~m} 3 / \mathrm{ha}$, an average mean annual increment of $1.1 \mathrm{~m} 3 / \mathrm{ha} /$ year and average stand ages from 80 to 300 years.

The sustainable development of the forest resource in the Yukon is currently the responsibility of the federal government, Department of Indian Affairs and Northern Development (DIAND). Before 1995, forest management in the Yukon, with the exception of fire management, was limited. An unprecedented demand for wood in the Yukon in the summer of 1994/95 resulted in DIAND expanding the forest resources program by hiring a number of professional foresters, updating stumpage and policy regimes and establishing a reforestation program funded by a levy. For example, stumpage was raised from .20 cents $/ \mathrm{m} 3$ to $\$ 2.62$ and $\$ 5.26 / \mathrm{m} 3$ depending on the sawlog destination inside or outside the Yukon. These actions were directed by the federal government's firm commitment to meet its sustainable development commitments.

The Yukon government has limited control over the development of the Yukon's natural resources, since forestry, lands, water and mineral resources are pending the transfer to the Yukon government from the federal government. Yukon government does have jurisdiction over wildlife, tourism, economic development, transportation, health and welfare, parks and protected areas, agriculture, and fresh water fisheries. Recent First Nations Final Land Claims Agreements (FNFLCA) and self government agreements have established new roles and responsbilities for all levels of governments including First Nations in resource management. A First Nation with final land claim has absolute jurisdiction of its resource as defined under the FNFLCA and the laws of general application.

The federal and Yukon governments recognize the need for change in current forest management practices and the need to prepare for the future transfer of administrative control of the forest resource and are cooperating in the development of

\footnotetext{
${ }^{1}$ Chairman, Klondike Section, Canadian Institute of Forestry, Whitehorse, Yukon.
}

a new Yukon forest strategy. A draft paper released for public review and comment outlines principles and actions to:

- implement ecosystem-based management

- encourage investment and diversity in a sustainable forest economy

- begin development of regional forest management plans

- provide a framework for the

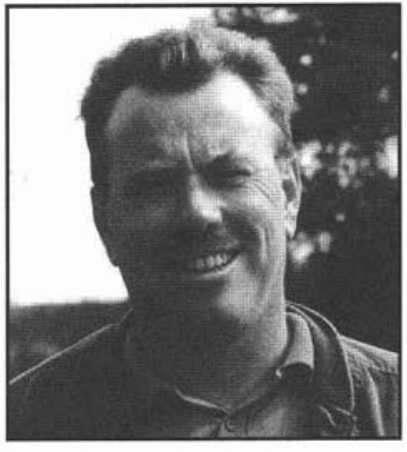
creation of a Yukon Forest Act and guide the transfer of control of forest resources on non-settlement lands from Canada to the government of the Yukon.

The sustainable development of the Yukon's forests now calls for use of ecosystem-based management. This concept considers forest activities from social, environmental, and economic aspects within a defined area over the short and long term.

There are four fundamental principles underlying ecosystembased management: public involvement, ecological approach, partnerships, and management based on sound science and traditional knowledge. Ecosystem-based management needs to transcend political, institutional and economic boundaries in order to achieve the goals set out in our country's National Forest Strategy.

Sustainable forest management in the Yukon requires the development of strategies which reflect the social, environmental, and economic aspects of the Yukon.

\section{Social Aspects - Community Involvement}

The key difference between the Yukon and the rest of Canada, is the unique relationship with the First Nations and other orders of government (DIAND 1993). Sustainable forest development is explicit in the inter-governmental relationship as defined in the Umbrella Final Agreement (UFA) and FNFLCA. On May 29, 1993, Yukon First Nations (YFN), federal and Yukon governments and the Council for Yukon Indians signed historic UFA and FNFLCAs with four Yukon First Nations. The UFA established the basis for the negotiation of individual settlements with each of the 14 First Nations. It also provides for the negotiation of self-government agreements with Yukon First Nations. As of October 1, 1997, six FNFLCA have been signed.

When completed, the 14 FNFLCAs will provide for 41,595 $\mathrm{km}^{2}$ of settlement land, of which $25,900 \mathrm{~km}^{2}$ include subsurface mineral rights. In addition, Yukon First Nations will benefit from rights in the management of national parks and wildlife areas, specific rights for fish and wildlife harvesting, special economic and employment opportunities, provide for financial compensation of \$242 million dollars (1989) over 15 years, and the establishment of boards, committees and tribunals to oversee resource management aspects of the agreements.

Chapter 17 of the UFA, "Forest Resources", outlines the following principles: 
- each Yukon First Nation will own, manage, allocate and protect forest resources on its settlement lands

- forest resources include all flora in the wild state

- management of forest resources involves the control of fire, diseases and pests, and logging on settlement land

- Renewable Resources Councils were created to oversee local renewable resources management in traditional territories as set out in the FNFLCA. The Renewable Resources Councils make recommendations on matters such as fish and wildlife and forest resources. Renewable Resources Councils consist of community members appointed by First Nation, Yukon and Federal governments.

- provisions for third party interest, access to settlement lands, and economic opportunities.

Each FNFLCA creates a Renewable Resources Council for a given traditional territory that includes both settlement land and Crown land. The role of the Renewable Resources Council is to advise governments on management issues as they pertain to fish and wildlife and forest resources in the traditional territory. As well, a land use planning commission has been created to oversee the development of regional land use plans for each traditional territory.

FNFLCA may include all provisions of the UFA along with specific provisions that apply specifically to that individual YFN. FNFLCAs are also constitutionally protected under section 35 of the Charter of Rights and Freedoms.

Over the past two years, the participation of First Nations in forest management in the Yukon has taken hold in direct recognition of DIAND's fiduciary responsibilities under UFA. Areas currently or proposed for cooperation for capacitybuiding are, inventory and planning, regulation and industrial development, Yukon First Nations Forestry Program, GIS/data sharing, contract fire suppression crews, and demonstration forest.

Recommendations mad by the Renewable Resources Councils must recognize FNFLCA and jurisdictional responsibilities of both federal and Yukon governments. Forest management must be coordinated with the provisions of the UFA and FNFLCA and other resource development processes such as the Canadian Environmental Assessment act, Development Assessment process, and Yukon land Use planning process. The objective of community-based planning is to develop communitybased guidelines for forest protection, harvesting, renewal, and utilization.

In 1996, DIAND in cooperation with other orders of government established a citizens-led Yukon Forest Advisory Committee. This committee oversees the Elijah Smith Reforestation Program and provides feedback and advice to governments on various forestry related initiatives.

Any community-based direction must reflect the environmental realities of the defined forest land base.

\section{Environmental Aspects}

Proper stewardship of the forests of the Yukon must embody the following principles:

Ecological Sustainability - Yukon forests will be recognized as ecosystems and key forest management activities will be managed in ways that conserve ecological integrity, biological diversity, long term forest productivity and forest land bases. Ecological sustainability will take precedent in management of Yukon's forests.
Precautionary Principle - Caution will be exercised when consequences of actions in the forest are uncertain. Where there is a threat of serious or irreversible damage to any forest ecosystem, activities will be curtailed unless appropriate reclamation measures are available and can be implemented.

Adaptive Management - This approach will be based on the best available scientific and indigenous knowledge, and monitoring information to improve forest management practices.

Yukon First Nations Values, Traditions, and Cultures - Yukon First Nations are recognized as equal partners with the Federal and Yukon governments in managing the Yukon forests. First Nation culture and traditional knowledge will be a cornerstone of forest management planning and practices.

The last major aspect of sustainable forest management addresses those key economic aspects which can affect the community and the environment the most.

\section{Economic Aspects}

The potential for any sustained economic growth in the forest sector in the Yukon is dependent on the development of appropriate forest resources allocation and tenure regimes within existing institutional frameworks. Some key characteristics of the current institutional and regulatory environment are the dominance of the federal Government as forest managers with the expectation of transferring the forest resources mandate to the Yukon, the volatility of commercial forestry in the Yukon corresponding to extra-territorial market pricing, the pending completion of land claims, no long term tenure (more than five years), extent of quality forest resources inventory and an absence of an integrated economic development strategy for the forest sector. Also, there is a need to encourage integration among responsible resource management agencies to forge new partnerships among all responsible for forest management.

Any Yukon tenure and allocation system should be designed to encourage the development of income opportunities in special forest products for rural entrepreneurs (e.g., aeromatics, berries, cones and seeds, honey, mushrooms, weaving and dying material, specialty wood products) and the development of renewable energy technologies such as biomass energy.

A tenure and allocation system needs to support existing primary and secondary value-added forest products industries and their orderly growth through access to capital and quality wood in a timely and secure fashion while sustaining traditional product use and opportunities for residents and First Nations (DIAND 1996).

A proper tenure and allocation system must be able to capture economic benefits from cyclical spikes in demand for timber from outside the Yukon by placing under long term management a percentage of the annual allowable cut in each forest management unit (DIAND 1996).

In support of an effective tenure and allocation system, there is a need for alternative service delivery mechanisms for forest management in the Yukon and a fully financed reforestation program for all silviculture requirements on Crown land. Partnerships are the key to a successful delivery. Finally, the allocation and harvest of forest resources must correspond to sustainable harvest levels below the biological carrying capacity of the defined forest management area. 


\section{Conclusion and Summary}

Forest management in the Yukon has the necessary elements to pursue sustainable development of the Yukon's forest resources. However, the federal government, in cooperation with Yukon and First Nation governments, must ensure the challenges are faced collectively and cooperatively as envisioned under the UFA.

Ecosystem-based management presents many challenges. The most important one is to be prepared to allow our individual and collective values and beliefs surrounding forest management to be challenged and perhaps changed. Ecosystem-based management is not one specific goal or program, it is an overall concept that influences the way our forests are managed. The concept may result in some fundamental shifts in traditional beliefs in our systems of governance and resource management. In all cases, resource managers will be expected to report publicly with demonstrable proof that we are managing sustainably.

\section{Acknowledgements}

The author would like to thank Linda, his wife and fellow professional forester, and Mr. Denis Senger, Communications Coordinator for the Yukon Department of Renewable Resources, for their patience in reviewing this document.

\section{References}

DIAND. 1993. Umbrella Final Agreement with Council for Yukon Indians. Minister of Supply and Services Canada 1993. 292 p.

DIAND. 1996. Dept. of Indian Affairs and Northern Development Yukon Timber Allocation and Forest Activity Review. Internal Report. $20 \mathrm{p}$.

Natural Resources Canada. 1997. The State of Canada's Forests 1996-1997. 128 p. 